\title{
The role of rhizobacteria in the stimulation of the growth and development processes and protection of plants against environmental factors
}

\author{
Rola bakterii ryzosferowych w stymulacji procesów wzrostu \\ i rozwoju oraz ochronie roślin przed czynnikami środowiska
}

\author{
Grażyna Dąbrowska*, Ewelina Zdziechowska
}

\begin{abstract}
Summary
Plant growth promoting rhizobacteria (PGPR) have a positive impact on the growth and development of plants, directly through the production of plant hormones or facilitate nutrient uptake from the environment and indirectly by reducing harmful effect or protection against phytopathogenic organisms. Impact of PGPR on plant growth processes includes increasing the speed of germination, root and shoot growth, an increase in chlorophyll content, magnesium, nitrogen, protein content and hydraulic conductance. These bacteria can also produce antibiotics and hydrogen cyanide, which inhibit the growth of harmful microorganisms in the rhizosphere. Some secrete organic acids, causing an increase in the bioavailability of the trace elements in the soil, other synthesize phytohormones and siderophores. PGPR play a protective role in stress conditions such as drought, salinity, heavy metals, hypoxia, temperature changes and to pathogen's attacks. PGPR strains which stimulate growth and development are known for most crop plants. It seems that the controlled use of PGPR in field crops could potentially contribute to the restriction of the use of chemical fertilizers and herbicides.
\end{abstract}

Key words: plant growth promoting rhizobacteria; PGPR; plant stress; the growth of plants

\begin{abstract}
Streszczenie
Bakterie ryzosferowe stymulujące wzrost roślin (PGPR - plant growth promoting rhizobacteria), wpływają pozytywnie na wzrost i rozwój roślin w sposób bezpośredni poprzez produkcję fitohormonów lub ułatwienie pobierania składników odżywczych ze środowiska oraz pośrednio poprzez zmniejszenie szkodliwości lub ochronę przed działaniem organizmów fitopatogenicznych. Wpływ PGPR na rośliny obejmuje m.in. zwiększenie szybkości kiełkowania, wzrost korzenia i pędu, wzrost zawartości chlorofilu, mikroelementów i białek oraz przewodnictwa hydraulicznego. Bakterie te mogą hamować rozwój patogenów, wydzielać kwasy organiczne, powodując wzrost biodostępności pierwiastków śladowych w glebie lub syntetyzować fitohormony i siderofory. PGPR pełnią rolę ochronną $w$ warunkach stresowych, takich jak: susza, zasolenie, obecność metali ciężkich, niedotlenienie, zmiany temperatury oraz atak patogenów. Dla większości roślin uprawnych znane są szczepy PGPR stymulujące wzrost i rozwój. Wydaje się, że kontrolowane zastosowanie PGPR zwłaszcza w uprawach ekologicznych może potencjalnie przyczynić się do ograniczenia stosowania sztucznych nawozów mineralnych i herbicydów.
\end{abstract}

Słowa kluczowe: bakterie stymulujące wzrost roślin; PGPR; stres roślin; wzrost roślin

Uniwersytet Mikołaja Kopernika

Wydział Biologii i Ochrony Środowiska, Zakład Genetyki

Gagarina 9, 87-100 Toruń

*corresponding author: browsk@umk.pl 


\section{Wstęp / Introduction}

Bakterie ryzosferowe promujące wzrost roślin (PGPR plant-growth promoting rhizobacteria) kolonizują glebę dzięki zdolności adaptacji do różnych warunków środowiska, szybkiego tempa wzrostu oraz metabolizowania wielu związków (Bhattacharyya i Jha 2012). Ze względu na sposób zasiedlenia roślin dzielą się one na dwie grupy: wewnątrzkomórkowe bakterie symbiotyczne znajdujące się w wyspecjalizowanych strukturach komórek korzenia, takich jak brodawki oraz wolno żyjące bakterie zewnątrzkomórkowe, które obecne są w ryzosferze, na powierzchni korzeni oraz $\mathrm{w}$ przestrzeniach międzykomórkowych kory korzenia (Martinez-Viveros i wsp. 2010). Do wewnątrzkomórkowych PGPR należą m.in. bakterie rodzaju: Agrobacterium, Arthrobacter, Azotobacter, Azospirillum, Bacillus, Burkholderia, Caulobacter, Chromobacterium, Erwinia, Flavobacterium, Micrococcous, Pseudomonas oraz Serratia (Bhattacharyya i Jha 2012). Do zewnątrzkomórkowych PGPR zaliczamy bakterie rodzaju Frankia oraz bakterie endofityczne z rodziny Rhizobiaceae: Allorhizobium, Azorhizobium, Bradyrhizobium, Mesorhizobium i Rhizobium (Verma i wsp. 2010).

PGPR stymulują wzrost roślin w sposób bezpośredni i pośredni. Pierwszy z nich polega na produkcji fitohormonów stymulujących wzrost, redukowaniu poziomu etylenu oraz ułatwieniu pobierania związków mineralnych. Z kolei stymulacja pośrednia opiera się na ochronie przed fitopatogenami (Kalitkiewicz i Kępczyńska 2008). Liczebność mikroorganizmów bytujących w ryzosferze jest nawet 100 razy większa $\mathrm{w}$ porównaniu $\mathrm{z}$ powierzchniowymi warstwami gleby, ponad $15 \%$ powierzchni korzenia może być pokryte mikrokoloniami różnych szczepów bakteryjnych (van Loon 2007). Martyniuk (2012) w badaniach dotyczących występowania w glebach Polski bakterii symbiotycznych roślin strączkowych i zakażenia nasion tych roślin preparatami zawierającymi rizobia wykazał, że liczebność symbiontów grochu i bobiku była zróżnicowana. W niektórych glebach stwierdzono dużą liczebność (ponad 1000 komórek/g), w innych glebach średnią (powyżej 100 do 1000 komórek/g) lub małą liczebność (do 100 komórek/g), a w glebach lekkich i zakwaszonych nie wykryto bakterii symbiotycznych tych roślin. Liczebność i zróżnicowanie mikroorganizmów w glebie wpływające na wydajność produkcji rolniczej, zależą m.in. od wilgotności gleby, $\mathrm{pH}$, obecności biomasy roślin i dostępności azotu (Borowik i wsp. 2010).

Celem pracy było podsumowanie wiedzy na temat bakterii ryzosferowych i ich funkcji, jakie pełnią towarzysząc roślinom podczas wzrostu i rozwoju w środowisku naturalnym, a także w warunkach stresu środowiskowego spowodowanego czynnikami abiotycznymi i biotycznymi. W pracy zwrócono uwagę na ochronną rolę bakterii PGPR i możliwość ich zastosowania jako składników biopreparatów potencjalnie przydatnych w uprawach ekologicznych i w rolnictwie.

\section{Stymulacja bezpośrednia wzrostu i rozwoju roślin przez PGPR / Direct stimulation growth and development of plants by PGPR}

Bakterie PGPR stymulują wzrost roślin poprzez produkcję fitohormonów: auksyn, giberelin i cytokinin (Martinez-Viveros i wsp. 2010). Ważnymi fitohormonami syntetyzowanymi przez PGPR są auksyny. Wpływ tych hormonów zależy od ich stężenia - niskie stężenie może stymulować rozwój siewek, natomiast stężenie zbyt wysokie działa hamująco (Sivasankari i wsp. 2014). Najlepiej poznaną auksyną jest kwas indolilo-3-octowy (IAA indole-3-acetic acid), który odpowiada za podział, wzrost i różnicowanie komórek oraz tkanek roślinnych. Egzogenny IAA w niskim stężeniu $\left(10^{-9}\right.$ i $\left.10^{-12} \mathrm{M}\right)$ stymuluje wzrost wydłużeniowy korzenia głównego, w dużym stopniu przyczynia się do tworzenia korzeni bocznych oraz włośników (Pilet i Saugy 1987). Z kolei dodanie do podłoża tryptofanu (prekursor IAA) w niskim stężeniu miało znacznie lepszy wpływ na wspięgę wężowatą (Vigna unguiculata) niż jego dodatek w stężeniu wyższym. Zaobserwowano wówczas zwiększenie powierzchni liści oraz długości pędów i korzeni (Sivasankari i wsp. 2014). PGPR najczęściej wytwarzają ten fitohormon $\mathrm{z}$ kwasu indolilopirogronowego, a bakterie fitopatogeniczne produkują IAA z indoliloacetamidu. Przykładem jest Agrobacterium tumefaciens, której auksyna indukuje tworzenie się guzów oraz Pseudomonas syringae przyczyniająca się do powstawania narośli (Persello-Cartieaux i wsp. 2003). Wśród PGPR najlepiej poznaną bakterią syntetyzującą kwas indolilo-3-octowy jest Azospirillum. IAA produkują również: Aeromonas, Burkholderia, Enterobacter, Pseudomonas (Martinez-Viveros i wsp. 2010) i Bacillus (Swain i wsp. 2007). Szczepienie nasion storczyka bakteriami Sphingomonas sp. oraz produkującymi IAA Mycobacterium sp. działała stymulująco na ich kiełkowanie (Pindi i wsp. 2013). Pozytywny wpływ na kiełkowanie nasion pomidora zaobserwowano w obecności Azospirillum brasilense Sp7-S (Mangmang i wsp. 2014). W eksperymencie, w którym pochrzyn zakażono zawiesiną Bacillus subtilis zaobserwowano wzrost świeżej masy, długości łodyg i korzeni w porównaniu do roślin niezakażonych (Swain i wsp. 2007). Wykazano, że korzenie pomidora i sałaty szczepionych $A$. brasilense Sp7-S i Sp245 i Herbaspirillum seropedicea były odpowiednio o około 28 i $26 \%$ dłuższe niż korzenie roślin stanowiących kontrolę (Mangmang i wsp. 2014). Z kolei Kosakonia radicincitans YD4, Rhizobium pusense YP3 oraz Pseudomonas putida YP2 wpływają pozytywnie na uprawę ostrokrzewu paragwajskiego (Bergottini i wsp. 2015).

Kolejnymi fitohormonami syntetyzowanymi przez PGPR są gibereliny. Biorą one udział w kiełkowaniu nasion, tworzeniu siewek, indukują kwitnienie oraz przyczyniają się do wzrostu kwiatów, owoców oraz powierzchni liści, stymulują wzrost korzeni i włośników. Spośród PGPR gibereliny wytwarzają następujące bakterie: Achromobacter xylosoxidans, Acinetobacter calcoaceticus, Azospirillum spp., Azotobacter spp., Bacillus spp., Herbaspirillum seropedicae, Gluconobacter diazotrophi- 
cus oraz Rhizobium. Zakażenie Arabidopsis thaliana bakterią $A$. brasilense Sp245 spowodowało wzrost stężenia giberelin u rzodkiewnika podczas stresu oksydacyjnego. Podobnie zaobserwowano zwiększenie zawartości giberelin w korzeniach kukurydzy zakażonych Azospirillum (Vacheron i wsp. 2013). Natomiast zakażenie fasoli szczepem Bradyrhizobium sp. wpływało na wydłużanie międzywęźli tej rośliny (Dobert i wsp. 1992). PGPR syntetyzują także cytokininy, należą do nich: Arthrobacter giacomelloi, A. brasilense, Bradyrhizobium japonicum, Bacillus licheniformis, Pseudomonas fluorescens oraz Paenibacillus polymyxa (Vacheron i wsp. 2013).

Cytokininy stymulują podział komórek roślinnych, indukują proliferację komórek włośników oraz hamują tworzenie korzeni bocznych i wydłużanie korzenia głównego, odpowiadają za dominację wierzchołkową, starzenie się liści, mobilizację składników odżywczych oraz kiełkowanie nasion i wzrost pędów (Vacheron i wsp. 2013). Bezpośrednia stymulacja poprzez PGPR polega na obniżaniu poziomu etylenu, który $\mathrm{w}$ wysokim stężeniu wpływa negatywnie na rozwój roślin. Pod wpływem stresu związanego $\mathrm{z}$ niską temperaturą, suszą, anoksją, infekcją patogenami oraz obecnością metali ciężkich rośliny syntetyzują kwas 1-aminocyklopropano-1-karboksylowy (ACC - 1-aminocyclopropane-1-carboxylic acid) będący prekursorem etylenu. ACC jest wydzielany do ryzosfery i ponownie adsorbowany przez korzenie, gdzie pod wpływem syntazy ACC ulega przekształceniu do etylenu. Hormon ten indukuje defoliację oraz procesy prowadzące do zahamowania wzrostu korzeni i łodyg, a także przedwczesne starzenie. Niektóre PGPR posiadają gen acdS kodujący deaminazę ACC, która rozkłada etylen do amoniaku i $\alpha$-ketomaślanu. Do bakterii tych należą: Achromobacter, Azospirillum, Enterobacter, Pseudomonas (Martinez-Viveros i wsp. 2010), Bacillus (Ghosh i wsp. 2008) oraz Rhizobium (Duan i wsp. 2009). Oprócz tego, że deaminaza skutecznie obniża poziom etylenu, to powstający w wyniku hydrolizy amoniak jest źródłem azotu, dzięki czemu bakterie mogą zasiedlać gleby o niskiej zawartości tego pierwiastka. Z doświadczenia przeprowadzonego przez Nadeema i wsp. (2010) wynika, że produkujące deaminazę ACC P. putida (W2) oraz P. fluorescens (W17) skutecznie chronią rośliny przed stresem związanym z zasoleniem. PGPR ułatwiają roślinom pobieranie związków mineralnych poprzez zwiększenie powierzchni korzeni, a bakterie diazotroficzne są zdolne do wiązania azotu atmosferycznego $\left(\mathrm{N}_{2}\right)$, gdyż posiadają enzym - nitrogenazę - redukujący $\mathrm{N}_{2}$ do łatwo przyswajalnego amoniaku $\left(\mathrm{NH}_{3}\right)$ (Lenart 2011). Obserwowano przyrost biomasy łubinu żółtego w wyniku zakażenia nasion szczepionką zawierająca bakterie brodawkowate (Faligowska i Szukała 2010). Symbiotyczny mechanizm umożliwia związanie większości $\mathrm{N}_{2}$, jednak ogranicza się on do roślin bobowatych, takich jak: soja, groch, orzechy ziemne i lucerna (Lugtenberg i Kamilova 2009) oraz drzew i krzewów tworzących symbiozę $\mathrm{z}$ promieniowcami Frankia (Martinez-Viveros i wsp. 2010). Najlepiej poznanymi bakteriami symbiotycznie wiążącymi $\mathrm{N}_{2}$ są: Azoto- bacter spp., Bacillus spp. oraz Beijerinckia spp. (Bhattacharyya i Jha 2012). Z kolei mechanizm niesymbiotyczny jest typowy dla wolno żyjących diazotrofów, takich jak: Azospirillum (Lugtenberg i Kamilova 2009), Burkholderia (Estrada-De Los Santos i wsp. 2001) i Pseudomonas, które wpływają pozytywnie na wzrost roślin niemotylkowatych, np. pszenicy i rzepaku (Lenart 2011). Z kolei $K$. radicincitans YD4 oraz $P$. putida YP2, dzięki obecności genów odpowiedzialnych za wiązanie azotu, umożliwiają uzyskanie lepszych plonów popularnego w Ameryce Południowej ostokrzewu paragwajskiego służącego do wyrobu herbaty mate. Przykładowo sucha masa pędów roślin szczepionych $K$. radicincitans YD4 była o 183\% większa w porównaniu do roślin nieszczepionych, zaś zawartość azotu była większa o 30\% (Bergottini i wsp. 2015).

Kolejnym ważnym dla roślin pierwiastkiem jest żelazo (Fe). PGPR posiadają zdolność kontrolowania puli Fe dzięki sideroforom, niskocząsteczkowym niebiałkowym związkom, specyficznie wiążącym jony Fe(III). Odgrywają one ważną rolę $\mathrm{w}$ przeprowadzaniu $\mathrm{Fe} \mathrm{z}$ trudno dostępnych związków kompleksowych w łatwo przyswajalną formę (Jankiewicz 2009). Dzięki temu, że siderofory posiadają wysokie powinowactwo do żelaza, podczas jego niedoboru w glebie, bakterie PGPR wygrywają konkurencję o ten pierwiastek $\mathrm{z}$ innymi mikroorganizmami. Ponadto siderofory mogą ochronić rośliny przed rozprzestrzenianiem się patogenów dzięki gromadzeniu Fe(III) wokół korzenia (Martinez-Viveros i wsp. 2010). Do bakterii syntetyzujących te związki należą: $K$. radicincitans YD4, Rhizobium pusense YP3, P. putida YP2 (Bergottini i wsp. 2015), Bradyrhizobium japonicum, Rhizobium leguminosarum, Sinorhizobium meliloti (Bhattacharyya i Jha 2012), Pseudomonas (Jankiewicz 2009), Serratia oraz Streptomyces (Martinez-Viveros i wsp. 2010).

PGPR wytwarzają kwasy organiczne, dzięki czemu posiadają zdolność rozpuszczania nieprzyswajalnych związków fosforu, głównie fosforanu glinu i żelaza, zawartego w glebach kwaśnych oraz fosforanu wapnia obecnego w glebach o wysokim pH. Przykładem kwasów syntetyzowanych przez bakterie są: kwas cytrynowy, mlekowy, bursztynowy, jabłczanowy oraz szczawiowy. Tworzą one kompleksy ze wcześniej wspomnianymi związkami i uwalniają fosfor $(\mathrm{P}) \mathrm{w}$ formie dostępnej dla roślin, zwiększają dostępność P poprzez blokowanie miejsc wiązania tego pierwiastka znajdujących się na powierzchni cząsteczek gleby (Jones i wsp. 2008). Wśród bakterii produkujących kwasy organiczne znajdują się bakterie rodzaju: Bacillus, Burkholderia, Enterobacter, Klebsiella, Kluyvera, Streptomyces, Pantoea oraz Pseudomonas (MartinezViveros i wsp. 2010). W glebie obecny jest także fosfor organiczny, który ze związków organicznych jest uwalniany dzięki kilku enzymom, tj. niespecyficznej fosfatazie, fitazie oraz liazom hydrolizującym wiązanie C-P (Lugtenberg i Kamilova 2009). Do bakterii ryzosferowych syntetyzujących fitazy należą bakterie rodzaju: Bacillus, Burkholderia, Enterobacter, Pseudomonas, Serratia oraz Staphylococcus (Martinez-Viveros i wsp. 2010). 


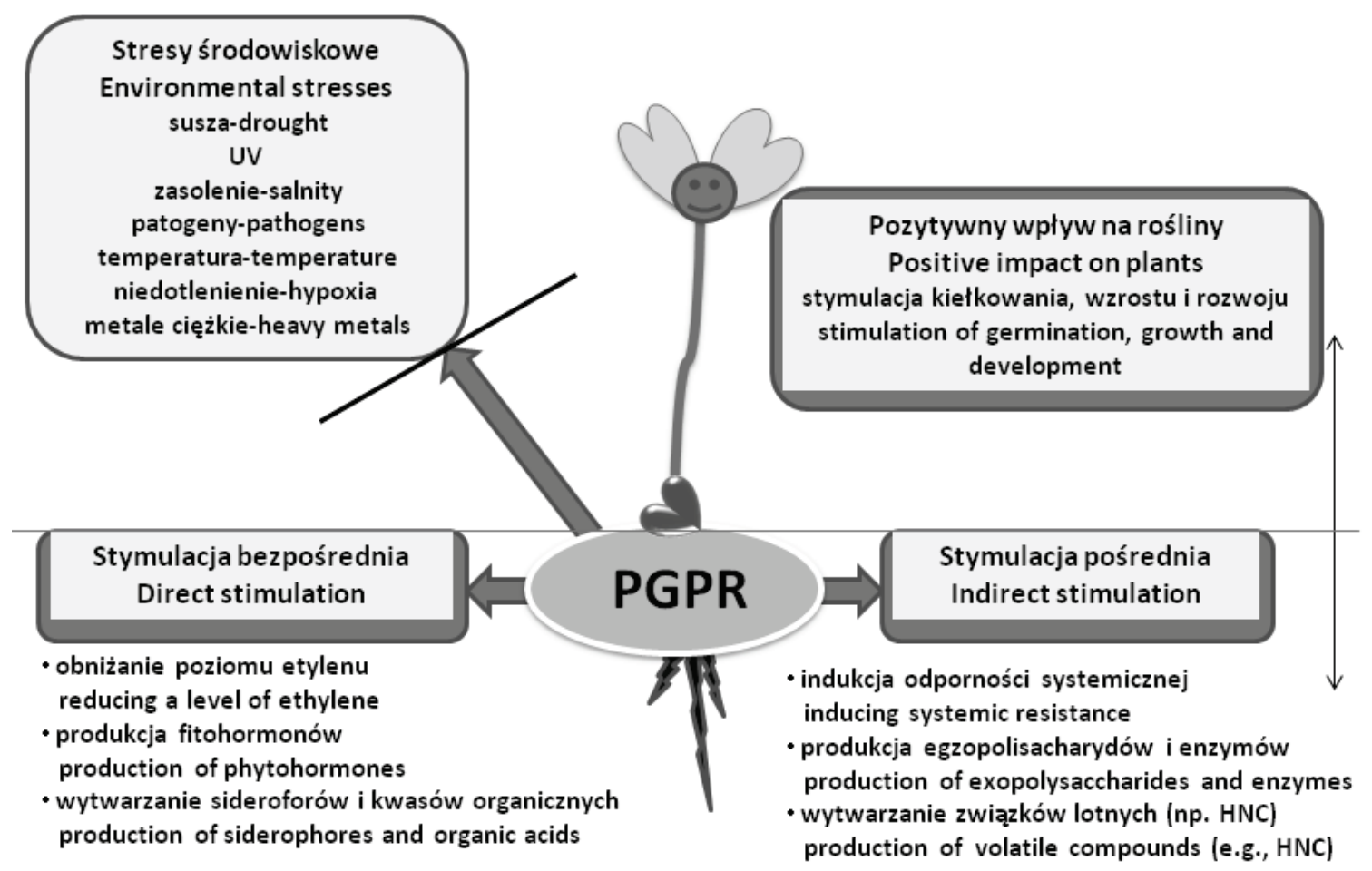

Rys. 1. Mechanizmy wykorzystywane przez PGPR (plant-growth promoting rhizobacteria) do stymulowania wzrostu roślin w warunkach stresowych

Fig. 1. The mechanisms used by PGPR (plant-growth promoting rhizobacteria) to stimulate the growth of plants under stress conditions

\section{Stymulacja pośrednia wzrostu roślin przez PGPR Indirect plant growth stimulation by PGPR}

Pośrednie mechanizmy stymulowania wzrostu roślin opierają się na biologicznym zwalczaniu patogenów oraz indukowaniu odporności systemicznej. Ochrona przed patogenami polega na produkcji antybiotyków oraz sideroforów ograniczających im pobieranie żelaza, konkurencji o niszę ekologiczną, syntezie metabolitów przeciwgrzybowych i enzymów rozkładających ściany komórkowe grzybów (Kalitkiewicz i Kępczyńska 2008). Antybiotyki stanowią dużą i niejednorodną grupę organicznych związków chemicznych o niskiej masie cząsteczkowej. Wśród antybiotyków syntetyzowanych przez PGPR znajdują się m.in.: butyrolakton, oligomycyna A, oomycyna A, ksantobakcyna (Martinez-Viveros i wsp. 2010), kanozamina, fenazyna, viscosinamid (Bhattacharyya i Jha 2012). Antybiotyki te działają przeciwwirusowo, przeciwbakteryjnie, przeciwgrzybowo i przeciwnowotworowo, chronią przed insektami oraz posiadają właściwości antyoksydacyjne. PGPR wytwarzające te związki to głównie bakterie rodzaju Bacillus i Pseudomonas (Fernando i wsp. 2006). Powyższe bakterie oraz Alcaligenes, Aeromonas, Rhizobium produkują cyjanowodór (HCN) skutecznie obniżający poziom zachorowań roślin i ograniczający rozwój patogenicznych grzybów (Devi i wsp. 2007). PGPR poprzez rośliny oddziałują także na owady, będące naturalnymi wrogami lub zapylaczami (Pineda i wsp. 2010). Przykładem są badania przeprowadzone z wykorzystaniem $P$. putida i Serratia marcescens, których obecność hamowała rozwój Acalymma vittatum i Diabrotica undecimpunctata, będących owadami żerującymi na ogórku (Zehnder i wsp. 1997). Kolejną strategią ochronną PGPR jest wytwarzanie enzymów litycznych. Substancjami hydrolizującymi ściany komórkowe patogenów są chitynazy (Compant i wsp. 2005). Związki te syntetyzowane przez bakterię Serratia plymuthica C48 hamują kiełkowanie zarodników oraz wzrost wydłużeniowy kiełkujących form Botrytis cinerea (Frankowski i wsp. 2001). Chitynazy wytwarzane przez S. marcescens skutecznie hamują rozwój Sclerotium rolfsii (Kalitkiewicz i Kępczyńska 2008), a produkowane przez Paenibacillus sp. 300 i Streptomyces sp. 385 uniemożliwiają rozwój Fusarium oxysporum $f$. sp. cucumerinum (Compant i wsp. 2005). W przypadku zakażenia ryżu patogenicznym Xanthomonas campestris zaobserwowano wzrost aktywności produkowanej przez Pseudomonas sp. BaC1-38 chitynazy o 73\% (Lucas i wsp. 2014). Do enzymów hydrolizujących zaliczamy także 1,3-glukanazy. W przypadku Paenibacillus sp. 300 oraz Streptomyces sp. 385 przeprowadzają one lizę ścian komórkowych $F$. oxysporum f. sp. cucumerinum (Singh i wsp. 1999). Z kolei te należące do Burkholderia cepacia niszczą ściany Rhizoctonia solani, Sclerotium rolfsii oraz Pythium ultimum (Compant i wsp. 2005). 1,3-glukanazy produkowane przez Pseudomonas sp. BaC1-38 chronią ryż przed $X$. campestris. Po zakażeniu roślin tym patogenem aktywność enzymu wzrosła aż o 778\% (Lucas i wsp. 2014). Bakterie PGPR odpowiadają za unieszkodliwianie i degradację czynników wirulencji patogenów. Przykładem może być nieodwracalna detoksykacja albicydyny Xanthomonas albilineans przez Pantoea dispersa lub produkcja przez Klebsiella oxytoca i Alcaligenes denitrificans białek wiążących tę toksynę (Zhang i Birch 1997). Niektóre mikroorganizmy, 
takie jak Burkholderia cepacia i Ralstonia solanacearum przeprowadzają hydrolizę kwasu fuzariowego - fitotoksyny syntetyzowanej przez Fusarium (Compant i wsp. 2005).

PGPR wytwarzają także siderofory wykazujące wyższe powinowactwo do żelaza niż fitopatogeny. Ograniczony dostęp do tego pierwiastka skutkuje zahamowaniem ich rozwoju, co wpływa pozytywnie na rośliny. Bakterie mogą stosować odmienną strategię, poprzez zapobieganie rozwojowi patogennych grzybów w wyniku zwiększenia zawartości żelaza w otoczeniu do poziomu, który działa na nie toksycznie. Przykładem jest P. fluorescens, hamująca w ten sposób rozwój Fusarium oxysporum oraz Pectobacterium carotovorum (Klama 2004).

Oddziaływania PGPR z korzeniami swoich gospodarzy mogą prowadzić do wytworzenia odporności na niektóre patogeniczne bakterie, grzyby i wirusy. Określa się ją jako indukowana odporność systemiczna (ISR - induced systemic resistance) (Lugtenberg i Kamilova 2009). Bakteryjnymi czynnikami posiadającymi zdolność do wywołania ISR są m.in.: lipopolisacharydy (lipid A i antygen O), siderofory (pseudobaktyna i piochelina), flagelle, antybiotyki (piocyjanina, 2,4-DAPG) oraz związki lotne (2,3-butanodiol) (Kalitkiewicz i Kępczyńska 2008). Raz aktywowana ISR utrzymuje się nawet po zmniejszeniu liczebności populacji bakterii, która ją zaindukowała (van Loon 2007). Oprócz bakterii kolonizujących korzenie, ISR mogą wzbudzić również: etylen, kwas arachidowy, kwas jasmonowy oraz kwas abscysynowy (Złotek i Wójcik 2007). Rolę cząsteczek sygnałowych w tym typie odporności pełnią jasmoniany $\mathrm{i}$ etylen, natomiast kontrolę nad nią sprawują białka regulacyjne NPR1 (Natriuretic Peptide Receptor-1) (Kalitkiewicz i Kępczyńska 2008). W przeciwieństwie do nabytej odporności systemicznej SAR (systemic acquired resistance) ISR nie powoduje żadnych widocznych objawów na roślinach. Przykładem bakterii indukujących ISR może być $P$. fluorescens EP1 chroniący trzcinę cukrową przed Colletotrichum falcatum oraz Bacillus pumilus SE34 chroniący korzenie grochu przed Fusarium oxysporum $f$. sp. pisi oraz korzenie bawełny przed $F$. oxysporum $f$. sp. vasinfectum (Compant i wsp. 2005). W celu ograniczenia występowania chorób zbóż przenoszonych z ziarnem stosowane były bakterie Propionibacterium freudenreichii spp. shermanii oraz Lactobacillus rhamnosus. Autorzy wykazali, że bakterie te skutecznie chroniły ziarno zbóż jęczmienia przed patogenem Pyrenophora graminea powodującym pasiastość liści jęczmienia (Kubiak i wsp. 2012).

\section{Ochronna rola PGPR przed niekorzystnymi czynnikami środowiskowymi Protective role of PGPR against unfavorable environmental factors}

\section{Susza}

Stres związany z suszą ogranicza wzrost oraz produktywność roślin uprawnych. Degradacja ACC umożliwia normalny wzrost roślin oraz redukuje stres związany z suszą. Zakażenie Arabidopsis thaliana bakterią Paenibacillus polymyxa zwiększyło tolerancję rośliny na suszę (Yang i wsp. 2009). Podobnie było w przypadku zakażenia pieprzu i pomidorów bakterią syntetyzującą deaminazę ACC - Achromobacter piechaudii ARV8 (Mayak i wsp. 2004a). Enzym ten rozkłada prekursor etylenu (ACC), który wpływa negatywnie na wzrost korzeni i łodyg (Martinez-Viveros i wsp. 2010). Z kolei zakażenie kukurydzy Azospirillum brasilense podczas niedoboru wody zmniejszyło spadek potencjału wody oraz przyczyniło się do zwiększenia długości korzenia, powierzchni liści oraz biomasy (Casanovas i wsp. 2002). Zakażenie pszenicy Azospirillum zmniejszyło straty plonów podczas deficytu wody, zaobserwowano wzrost potencjału i zawartości wody w liściach poprzez to, że obecność bakterii stymulowała wzrost korzeni (Dimkpa i wsp. 2009). Bakterie rizobia są wrażliwe na stres związany z suszą. Przy niskiej zawartości wody w glebie wiążą znacznie mniej azotu atmosferycznego. Podczas suszy równoległe zakażenie fasoli Rhizobium tropici oraz dwoma szczepami Paenibacillus polymyxa spowodowało wzrost rośliny, zwiększenie suchej masy pędów oraz ilości brodawek (Yang i wsp. 2009). Zaprawianie nasion szparagów bakteriami PGPR stymulowało ich rozwój w warunkach suszy (Liddycoat i wsp. 2009). Mikroorganizmy rozpuszczające fosforany mogą natomiast pozytywnie oddziaływać na rośliny poprzez zwiększenie dostępności fosforu, co prowadzi, w przypadku kukurydzy, do wzrostu tolerancji rośliny na deficyt wody (Ehteshami i wsp. 2007). Bakterie strefy korzeniowej oprócz ACC wydzielają osmolity, czyli związki zwiększające potencjał osmotyczny. Przykładem jest betaina glicynowa, która zwiększa tolerancję na suszę (Dimkpa i wsp. 2009). Niekorzystnie na rośliny wpływa także nadmiar wody, a ochronną rolę w takich warunkach mogą pełnić bakterie syntetyzujące ACC. Dla przykładu zakażenie pomidora bakteriami Enterobacter cloacae oraz P. putida znacznie zwiększyło tolerancję roślin na stres związany z zalewaniem (Grichko i Glick 2001).

\section{Zasolenie gleby}

Negatywny wpływ na rośliny wywiera również duże zasolenie gleby. Zakażenie, narażonych na duże zasolenie, siewek pomidora bakterią wytwarzającą enzym ACC - A. piechaudii zredukowało zawartość etylenu (Mayak i wsp. 2004b). Z kolei P. fluorescens TDK1 syntetyzujący ACC znacznie silniej stymulował wzrost orzechów ziemnych uprawianych na zasolonych ziemiach niż szczep pozbawiony tego enzymu (Saravanakumar i Samiyappan 2007), natomiast zakażenie pszenicy Bacillus insolitus oraz Bacillus sp. zwiększyło tolerancję roślin na stres związany z umiarkowanym zasoleniem gleby (Ashraf i wsp. 2004). Zakażenie ryżu Pseudomonas sp. BaC1-38 zredukowało skutki stresu związanego $\mathrm{z}$ zasoleniem o $80 \%$, natomiast zakażenie bakterią Chryseobacterium sp. BaC1-13 o 50\%, zaś Pseudomonas sp. BaC1-21 o 20\% (Lucas i wsp. 2014). Azospirillum sp. wpływa na akumulację substancji rozpuszczalnych, takich jak: glutaminian, prolina, betaina glicynowa i trehaloza, które odgrywają ważną rolę w osmoadaptacji. Sorgo, zakażone Azospirillum, charakteryzowało się większą zawartością wody, wyższym potencjałem wodnym oraz niższą temperaturą w osłonkach liści (Tripathi i wsp. 1998). Natomiast pszenica zakażona 
P. putida i P. fluorescens nawet w warunkach wysokiego zasolenia miała znacznie dłuższy korzeń i pędy, większą biomasę oraz dawała większe plony niż rośliny niezakażone (Nadeem i wsp. 2010).

\section{Zmiany temperatury}

Niekorzystne skutki dla roślin ma także skrajnie wysoka lub niska temperatura. Wydłużenie korzenia jest możliwe tylko powyżej minimalnej temperatury, a ta z kolei zależy od gatunku rośliny. Im temperatura $(T)$ jest wyższa tym szybszy jest wzrost korzenia, a przekroczenie maksymalnej wartości T powoduje gwałtowne orgraniczenie wydłużania. Szczepienie ziemniaków Burkholderia phytofirmans wpływa na adaptację tej rośliny do podwyższonej temperatury. W przypadku roślin zakażonych, powstawanie zawiązków bulw było nawet o $63 \%$ większe w stosunku do kontroli (Dimkpa i wsp. 2009). Z kolei zaszczepienie tą samą bakterią winorośli zmniejszyło tempo redukcji biomasy $\mathrm{w}$ niskiej temperaturze $\left(4^{\circ} \mathrm{C}\right)$ i wpływało na zwiększenie poziomu węglowodanów, proliny oraz fenoli (Barka i wsp. 2006).

\section{Metale ciężkie}

Obecność znacznej ilości metali ciężkich w glebie wpływa negatywnie na kiełkowanie, wzrost i rozwój roślin, ale przed ich niekorzystnymi skutkami chronią niektóre bakterie ryzosferowe (Dąbrowska i wsp. 2010, 2011a). Bakterie rodzaju: Arthrobacter, Klebsiella, Pseudomonas oraz Bacillus są odporne na toksyczne działanie metali ciężkich. Posiadają one zdolność akumulacji jonów metali w obrębie lub poza komórką. Mogą także wymieniać jony $\mathrm{z}$ polianionami obecnymi w bakteryjnej ścianie komórkowej. Jęczmień uprawiany na glebie zanieczyszczonej kadmem (Cd) oraz zakażony Klebsiella mobilis CIAM 880 dał o $120 \%$ większy plon, a zawartość $\mathrm{Cd}$ w ziarnach była dwukrotnie mniejsza (Pishchik i wsp. 2002). Rzepak jary i ozimy w zależności od odmiany był chroniony przed szkodliwym działaniem metali ciężkich przez szczepy: Bacteroidetes bacterium, Bacillus sp. i Flavobacterium, a obecność bakterii PGPR wpływała na zmiany ekspresji genu metalotioneiny (Dąbrowska i wsp. 2011b, 2012). Toksyczność żelaza stanowi poważne ograniczenie w uprawie ryżu. Według doniesień, toksycznemu działaniu Fe zapobiegają niektóre szczepy Bacillus (Dimkpa i wsp. 2009). Z kolei kapusta sitowata zakażona szczepami PGPR, które wytwarzają IAA i siderofory (A3 oraz S32), wykazała silniejszy wzrost w glebie zanieczyszczonej chromem (Rajkumar i wsp. 2009). Siderofory niektórych bakterii chronią także rośliny przed toksycznym działaniem niklu, ołowiu i cynku (Dimkpa i wsp. 2009).

\section{Znaczenie aplikacyjne PGPR stanowiących składniki biostymulatorów Biostimulators and rhizosphere bacteria}

Badania dotyczące mikrobiologii gleby prowadzone przez wiele ośrodków badawczych w kraju i za granicą umożliwiły zidentyfikowanie oraz scharakteryzowanie wielu istotnych grup mikroorganizmów, które mogą być wykorzystywane w praktykach rolnictwa przede wszystkim integrowanego i ekologicznego. Do bakterii PGPR należą - Bacillus megaterium i Pantoea agglomerans, które pod względem niektórych właściwości (produkcja aminokwasów, hormonów, kwasów organicznych, zawartości pierwiastków i aktywność enzymów antyoksydacyjnych) mogą stanowić źródło składników pokarmowych dla roślin i pełnić biokontrolę nad mikroorganizmami patogennymi (Gunes i wsp. 2015). Preparaty biologiczne stosowane są w celach: promowania wzrostu roślin, uzyskiwania wyższej biomasy i wydajności, ochrony roślin przed patogenami i szkodnikami roślin uprawnych (Martyniuk i Księżak 2011). Obecnie produkowane są biopreparaty oparte o drobnoustroje, w tym zawierające bakterie PGPR, bakterie brodawkowe roślin motylkowych, a także grzyby mikoryzowe. Stosunkowo dużą popularnością cieszy się preparat o nazwie Efektywne Mikroorganizmy $E M \circledast$, jednak badania nie wykazały jednoznacznie pozytywnego wpływu tego preparatu na zdrowotność pszenicy jarej, nie były też efektywne w zapobieganiu gorzkiej zgniliźnie jabłek wywoływanej przez Pezicula spp. (Bryk i Rutkowski 2012; Zbroszczyk i Kordas 2012). Na rynku krajowym dostępne są także preparaty pod nazwami: Hansespor ${ }^{\circledR}$ Dry Mix, Nitragina, Azotobakteryna, Asahi SL, Atonik SL, EM5, EM-Farming, Desol, Yellow Jacket i inne. Stosowanie biopreparatów może mieć wpływ na podniesienie jakości i wydajności z upraw roślin użytkowych oraz obniżenie kosztów rolnictwa zwłaszcza ekologicznego. Należy jednak zwrócić uwagę na fakt, że nie stwierdzono bakterii glebowych, które jednakowo wydajnie stymulowałyby rośliny do wzrostu, dlatego niezbędnym jest dopasowywanie bakterii PGPR do rodzaju, a nawet gatunku rośliny (Dąbrowska i wsp. 2012). Przykładem może być rzepak, w którym w doświadczeniach, w warunkach in vitro, w zależności od odmiany (jara, ozima), bakterie PGPR w różnym stopniu stymulowały kiełkowanie i wzrost tej rośliny (Dąbrowska i wsp. 2010, 2012). Badania Martyniuka i wsp. (2005) wskazują na podobne obserwacje, ponieważ w glebach dotychczas nie stwierdzono gatunku bakterii tworzących brodawki na wszystkich gatunkach roślin motylkowych (Martyniuk 2012). Rolnicy decydujący się na zastosowanie biopreparatów muszą mieć świadomość, że podczas wzrostu i rozwoju roślin, przede wszystkim zmieniające się warunki środowiska, stosowanie nawozów sztucznych i środków ochrony roślin decydują o wydajności z upraw. Jednocześnie czynniki te, a także stosowanie zapraw nasiennych mogą mieć wpływ na zmiany skuteczności preparatów mikrobiologicznych wykorzystywanych w uprawach polowych (Dąbrowska i wsp. 2010; Martyniuk i Księżak 2011; Martyniuk i wsp. 2014). Podczas wyboru biopreparatów należy zwrócić uwagę czy producent zawarł szczegółowe informacje dotyczące składu gatunkowego drobnoustrojów i ich liczebności w preparacie, co jest jednym $\mathrm{z}$ elementów świadczących o jego jakości. 
Wydaje się, że wzrastające zainteresowanie biopreparatami daje szansę na powszechniejsze ich użytkowanie, a tym samym uzyskiwanie żywności uznawanej za ekologiczną, która jest niezbędna do poprawy kondycji populacji ludzkiej.

\section{Podsumowanie / Summation}

Wzajemne oddziaływania nieantagonistyczne pomiędzy roślinami a mikroorganizmami, zwłaszcza bakteriami PGPR, przynoszą korzyści obu stronom, odgrywają istotną rolę podczas zasiedlania, a także przetrwania roślin $\mathrm{w}$ warunkach naturalnych $\mathrm{i} w$ środowisku zanieczyszczonym. Bakterie PGPR odgrywają ważną rolę w stymulacji wzrostu i rozwoju roślin oraz stanowią potencjalne źródło środków biologicznych wykorzystywanych do zwalczania szkodników i chorób roślin. Obecnie bakterie PGPR znalazły zastosowanie $\mathrm{w}$ ogrodnictwie, leśnictwie i bioremediacji środowiska. Bakterie te mogą częściowo zastąpić sztuczne nawozy mineralne oraz wykorzystywane na szeroką skalę pestycydy. W krajach Ameryki Łacińskiej w rolnictwie stosowane są szczepionki bakteryjne. Bradyrhizobium japonicum stosowano w uprawach soi w Argentynie, Brazylii, Boliwii i Urugwaju. Również do uprawy kukurydzy wykorzystywana jest bakteria PGPR A. brasilense (Castro-Sowinski i wsp. 2007). Kontrolowane stosowanie odpowiednio dopasowanych do gatunku rośliny szczepów bakterii PGPR stwarza nowe możliwości rozwoju rolnictwa. Identyfikacja najbardziej obiecujących szczepów bakteryjnych poprzez zapewnienie skutecznej selekcji i procedury badań przesiewowych stanowi jedno z wyzwań w rozwoju komercyjnych zastosowań PGPR. Nadal trudnym zadaniem jest osiągnięcie wydajnej aplikacji PGPR w warunkach polowych, gdzie występuje konkurencja $\mathrm{z}$ autochtonicznymi organizmami i różnorodność czynników biotycznych i abiotycznych. Wiedza na temat samej gleby i mechanizmów ochronnych wykorzystywanych przez rośliny w warunkach stresowych, a przede wszystkim strategie stosowane w uprawach są niezwykle istotne dla utrzymania różnorodności i przeżywalności stosowanych szczepów bakteryjnych.

\section{Literatura / References}

Ashraf M., Hasnain S., Berge O., Mahmood T. 2004. Inoculating wheat seedlings with exopolysaccharide-producing bacteria restricts sodium uptake and stimulates plant growth under salt stress. Biology and Fertility of Soils 40 (3): 157-162.

Barka E.A., Nowak J., Clément S. 2006. Enhancement of chilling resistance of inoculated grapevine plantlets with a plant growthpromoting rhizobacteria, Burkholderia phytofirmans strain PsJN. Applied and Environmental Microbiology 72 (11): $7246-7252$.

Bhattacharyya P.N., Jha D.K. 2012. Plant growth-promoting rhizobacteria (PGPR): emergence in agriculture. World Journal of Microbiology and Biotechnology 28 (4): 1327-1350.

Bergottini V.M., Otegui M.B., Sosa D.A., Zapata P.D., Mulot M., Rebord M., Zopfi J., Wiss V.F., Benrey B., Junier P. 2015. Bioinoculation of yerba mate seedlings (Ilex paraguariensis St. Hill) with native plant growth promoting rhizobacteria: a sustainable alternative to improve crop yield. Biology and Fertility of Soils 51 (6): 749-755.

Borowik A., Wyszkowska J., Kucharski M. 2010. Różnorodność drobnoustrojów funkcją uwilgotnienia gleby. Zeszyty Problemowe Postępów Nauk Rolniczych 567: 39-53.

Bryk H., Rutkowski K.P. 2012. Skuteczność proekologicznych metod ochrony jabłek przed gorzką zgnilizną (Pezicula spp.). [Efficacy of alternative methods in controlling of bull's eye rot (Pezicula spp.)]. Progress in Plant Protection/Postępy w Ochronie Roślin 52 (3): 727-732.

Casanovas E.M., Barassi C.A., Sueldo R.J. 2002. Azospirillum inoculation mitigates water stress effects in maize seedlings. Cereal Research Communications 30 (3-4): 343-350.

Castro-Sowinski S., Herschkovitz Y., Okon Y., Jurkevitch E. 2007. Effects of inoculation with plant growth-promoting rhizobacteria on resident rhizosphere microorganisms. FEMS Microbiology Letters 276 (1): 1-11.

Compant S., Duffy B., Nowak J., Clément C., Barka E.A. 2005. Use of plant growth-promoting bacteria for biocontrol of plant diseases: principles, mechanisms of action, and future prospects. Applied and Environmental Microbiology 71 (9): 4951-4959.

Dąbrowska G., Hrynkiewicz K., Kłosowska K., Goc A. 2011a. Selekcja bakterii ryzosferowych usprawniających procesy fitoremediacji gleb zawierających związki metali ciężkich. Ochrona Środowiska 33 (2): 53-58.

Dąbrowska G., Hrynkiewicz K., Kłosowska K., Trejgell A., Mierek-Adamska A. 2010. Wpływ bakterii ryzosferowych na kiełkowanie nasion Brassica napus L. w obecności metali ciężkich $(\mathrm{Cd}, \mathrm{Cu}, \mathrm{Pb}, \mathrm{Zn})$. Rośliny Oleiste-Oilseed Crops 31 (1): 85-97.

Dąbrowska G., Hrynkiewicz K., Mierek-Adamska A., Goc A. 2012. Wrażliwość odmian jarych i ozimych rzepaku na metale ciężkie i bakterie glebowe. Rośliny Oleiste-Oilseed Crops 33 (2): 201-220.

Dąbrowska G., Hrynkiewicz K., Trejgell A. 2011b. Wpływ PGPR (Plant Growth Promoting Rhizobacteria) na ekspresję metalotioneiny BnMT2 Brassica napus L. rosnącego w obecności metali ciężkich. Zeszyty Problemowe Postępów Nauk Rolniczych 567: 83-92.

Devi K.K., Seth N., Kothamasi S., Kothamasi D. 2007. Hydrogen cyanideproducing rhizobacteria kill subterranean termite Odontotermes obesus (Rambur) by cyanide poisoning under in vitro conditions. Current Microbiology 54 (1): 74-78.

Dimkpa C., Merten D., Svatos A., Buchel G., Kothe E. 2009. Metal-induced oxidative stress impacting plant growth in contaminated soil is alleviated by microbial siderophores. Soil Biology and Biochemistry 41 (1): 154-162.

Dobert R.C., Rood S.B., Blevins D.G. 1992. Gibberellins and the Legume-Rhizobium Symbiosis I. Endogenous Gibberellins of Lima Bean (Phaseolus lunatus L.) Stems and Nodules. Plant Physiology 98 (1): 221-224.

Duan J., Müller K.M., Charles T.C., Vesely S., Glick B.R. 2009. 1-aminocyclopropane-1-carboxylate (ACC) deaminase genes in rhizobia from southern Saskatchewan. Microbial Ecology 57 (3): 423-436. 
Ehteshami S.M., Aghaalikhani M., Khavazi K., Chaichi M.R. 2007. Effect of phosphate solubilizing microorganisms on quantitative and qualitative characteristics of maize (Zea mays L.) under water deficit stress. Pakistan Journal of Biological Sciences 10 (20): $3585-3591$.

Estrada-De Los Santos P., Bustillos-Cristales R., Caballero-Mellado J. 2001. Burkholderia, a genus rich in plant-associated nitrogen fixers with wide environmental and geographic distribution. Applied and Environmental Microbiology 67 (6): 2790-2798.

Faligowska A., Szukała J. 2010. Wpływ szczepienia nasion i nawożenia azotem na cechy biometryczne roślin strączkowych. Zeszyty Problemowe Postępów Nauk Rolniczych 550: 201-209.

Fernando W.G.D., Nakkeeran S., Zhang Y. 2006. Biosynthesis of antibiotics by PGPR and its relation in biocontrol of plant diseases. PGPR: Biocontrol and Biofertilization 3: 67-109.

Frankowski J., Lorito M., Scala F., Schmid R., Berg G., Bahl H. 2001. Purification and properties of two chitinolytic enzymes of Serratia plymuthica HRO-C48. Archives of Microbiology 176 (6): 421-426.

Ghosh S., Sengupta C., Maiti T.K., Basu P.S. 2008. Production of 3-indolylacetic acid in root nodules and culture by a Rhizobium species isolated from root nodules of the leguminous pulse Phaseolus mungo. Folia Microbiologica 53 (4): 351-355.

Grichko V.P., Glick B.R. 2001. Amelioration of flooding stress by ACC deaminase-containing plant growth-promoting bacteria. Plant Physiology and Biochemistry 39 (1): 11-17.

Gunes A., Karagoz K., Turan M., Kotan R., Yildrim E., Cakmakci R., Sahin F. 2015. Fertilizer efficiency of some plant growth promoting rhizobacteria for plant growth. Research Journal of Soil Biology 7 (2): 28-45.

Jankiewicz U. 2009. Charakterystyka i znaczenie piowerdyn bakterii z rodzaju Pseudomonas. Postępy Mikrobiologii 48 (4): $243-254$.

Jones D.L., Hodge A., Kuzyakov Y. 2008. Plant and mycorrhizal regulation of rhizodeposition. New Phytologist 163 (3): $459-480$.

Kalitkiewicz A., Kępczyńska E. 2008. Wykorzystanie ryzobakterii do stymulacji wzrostu roślin. Biotechnologia 2 (81): $102-114$.

Klama J. 2004. Współżycie endofitów bakteryjnych z roślinami. Agricultura Acta Scientiarum Polonorum 3 (1): 19-28.

Kubiak K., Gwiazdowski R., Gwiazdowska D. 2012. Badania nad zastosowaniem mieszaniny bakterii propionowych i mlekowych do ograniczenia występowania wybranych chorób zbóż przenoszonych z ziarnem siewnym. [Studies on application of mixture of propionic and lactic acid bacteria in the control of selected seed-borne cereal diseases]. Progress in Plant Protection/Postępy w Ochronie Roślin 52 (3): 603-606.

Lenart A. 2011. Wpływ inokulacji nasion azotobakteryną oraz Azotobacter chroococcum na przyrost biomasy pszenicy (Triticum vulgare VILL.), rzepaku (Brassica napus L. ssp. oleifera), kukurydzy (Zea mays L.), bobiku (Vicie faba L. ssp. minor). Zeszyty Problemowe Postępów Nauk Rolniczych 567: 159-166.

Liddycoat S.M., Greenberg B.M., Wolyn D.J. 2009. The effect of plant growth-promoting rhizobacteria on asparagus seedlings and germinating seeds subjected to water stress under greenhouse conditions. Canadian Journal of Microbiology 55 (4): 388-394.

Lucas J.A., Garcia-Cristobal J., Bonilla A., Ramos B., Gutierrez-Mañero J. 2014. Beneficial rhizobacteria from rice rhizosphere confers high protection against biotic and abiotic stress inducing systemic resistance in rice seedlings. Plant Physiology and Biochemistry 82: 44-53.

Lugtenberg B., Kamilova F. 2009. Plant-growth-promoting rhizobacteria. Annual Review of Microbiology 63: 541-556.

Mangmang J.S., Deaker R., Rogers G. 2014. Effects of plant growth promoting rhizobacteria on seed germination. Characteristics of tomato and lettuce. Journal of Tropical Crop Science 1 (2): 35-40.

Martinez-Viveros O., Jorquera M.A., Crowley D.E., Gajardo G., Mora M.L. 2010. Mechanisms and practical considerations involved in plant growth promotion by rhizobacteria. Journal of Plant Nutrition and Soil Science 10 (3): 293-319.

Martyniuk S. 2012. Naukowe i praktyczne aspekty symbiozy roślin strączkowych z bakteriami brodawkowymi. Polish Journal of Agronomy 9: 17-22.

Martyniuk S., Kozieł M., Gałązka A. 2014. Oddziaływanie zaprawy chemicznej na efektywność szczepienia nasion grochu bakteriami brodawkowymi. [Influence of chemical seed dressing on efficacy of pea seed inoculation with root-nodule bacteria]. Progress in Plant Protection 54 (3): 345-348.

Martyniuk S., Księżak J. 2011. Ocena pseudomikrobiologicznych biopreparatów stosowanych w uprawie roślin. Polish Journal of Agronomy 6: 27-33.

Martyniuk S., Oroń J., Martyniuk M. 2005. Diversity and numbers of root-nodule bacteria (rhizobia) in Polish soils. Acta Societatis Botanicorum Poloniae 74 (1): 83-86.

Mayak S., Tirosh T., Glick B.R. 2004a. Plant growth-promoting bacteria that confer resistance to water stress in tomatoes and peppers. Plant Science 166 (2): 525-530.

Mayak S., Tirosh T., Glick B.R. 2004b. Plant growth-promoting bacteria confer resistance in tomato plants to salt stress. Plant Physiology and Biochemistry 42 (6): 565-572.

Nadeem S.M., Zahir Z.A., Naveed M., Asghar H.N., Arshad M. 2010. Rhizobacteria capable of producing ACC-deaminase may mitigate salt stress in wheat. Soil Science Society of America Journal 74 (2): 533-542.

Persello-Cartieaux F., Nussaume L., Robaglia C. 2003. Tales from the underground: molecular plant-rhizobacteria interactionas. Plant, Cell and Environment 26 (2): 189-199.

Pilet P.-E., Saugy M. 1987. Effect on root growth of endogenous and applied IAA and ABA. Plant Physiology 83 (1): $33-38$.

Pindi P.K., Sultana T., Vootla P.K. 2013. Plant growth regulation of Bt-cotton through Bacillus species. 3 Biotech 4 (3): $305-315$.

Pineda A., Zheng S.-J., van Loon J.J.A., Pieterse C.M.J., Dicke M. 2010. Helping plants to deal with insects: the role of beneficial soilborne microbes. Trends in Plant Science 15: 507-514.

Pishchik V.N., Vorobyev N.I., Chernyaeva I.I., Timofeeva S.V., Koyhemyakov A.P., Alexeev Y.V., Lukin S.M. 2002. Experimental and mathematical simulation of plant growth promoting rhizobacteria and plant interaction under cadmium stress. Plant and Soil 243 (2): 173-186.

Rajkumar M., Ae N., Freitas H. 2009. Endophytic bacteria and their potential to enhance heavy metal phytoextraction. Chemosphere 77 (2): $153-160$.

Saravanakumar D., Samiyappan R. 2007. ACC deaminase from Pseudomonas fluorescens mediated saline resistance in groundnut (Arachis hypogaea) plants. Journal of Applied Microbiology 102 (5): 1283-1292. 
Singh P.P., Shin Y.C., Park C.S., Chung Y.R. 1999. Biological control of Fusarium wilt of cucumber by chitinolytic bacteria. Phytopathology 89 (1): 92-99.

Sivasankari B., Anandharaj M., Daniel T. 2014. Effect of PGR producing bacterial strains isolated from vermisources on germination and growth of Vigna unguiculata (L.) Walp. Journal of Biochemical Technology 5 (4): 808-813.

Swain M.R., Naskar S.K., Ray R.C. 2007. Indole-3-acetic acid production and effect on sprouting of Yam (Dioscorea rotundata L.) minisetts by Bacillus subtilis isolated from culturable cowdung microflora. Polish Journal of Microbiology 56 (2): 103-110.

Tripathi A.K., Mishra B.M., Tripathi P. 1998. Salinity stress responses in plant growth promoting rhizobacteria. Journal of Biosciences 23 (4): 463-471.

Vacheron J., Desbrosses G., Bouffaud M.L., Touraine B., Moënne-Loccoz Y., Muller D., Legendre L., Wisniewski-Dyé F., PrigentCombaret C. 2013. Plant growth-promoting rhizobacteria and root system functioning. Frontiers in Plant Science 4: 1-19.

van Loon L.C. 2007. Plant responses to plant growth-promoting rhizobacteria. European Journal of Plant Pathology 119 (3): $243-254$.

Verma J.P., Yadav J., Tiwari K.N., Lavakush S.V. 2010. Impact of plant growth promoting rhizobacteria on crop production. International Journal of Agricultural Research 5 (11): 954-983.

Yang J., Kloepper J.W., Ryu Ch.-M. 2009. Rhizosphere bacteria help plants tolerate abiotic stress. Trends in Plant Science 14 (1): 1-4.

Zbroszczyk U., Kordas L. 2012. Wpływ stosowania Efektywnych Mikroorganizmów EM® na zdrowotność pszenicy jarej uprawianej w krótkotrwałej monokulturze. [The influence of Effective Microorganisms EM ${ }^{\circledR}$ application on health status of spring wheat growing in short-term monoculture]. Progress in Plant Protection/Postępy w Ochronie Roślin 52 (2): 327-331.

Zehnder G., Kloepper J., Yao Ch., Wei G. 1997. Induction of systemic resistance in cucumber against cucumber beetles (Coleoptera: Chrysomelidae) by plant growth-promoting rhizobacteria. Journal of Economic Entomology 90 (2): 391-396.

Zhang L., Birch R.G. 1997. The gene for albicidin detoxification from Pantoea dispersa encodes an esterase and attenuates pathogenicity of Xanthomonas albilineans to sugarcane. Proceedings of the National Academy of Sciences USA 94 (18): 9984-9989.

Złotek U., Wójcik W. 2007. Wybrane aspekty nabywania u roślin odporności typu SAR. Acta Scientiarum Polonorum, Biotechnologia $6(2): 3-12$. 